DOI: https://doi.org/10.24113/ijellh.v9i1.10887

\title{
Which Cinderella You Want Your Daughter To Be?
}

\author{
Surasree Deb Barman \\ State Aided College Teacher \\ Birsa Munda College \\ West Bengal, India \\ surasreedev1996@gmail.com
}

\begin{abstract}
:
Modern age has provided great opportunities in all domains of people's lives, but it has also generated unexpected obstacles; one of which is a negative change in the concept of beauty in society. The new emerging tendency of people to appear like a supermodel in social media and to draw the interest of others by adding beauty filters not only sends an ambiguous message about beauty, but also produces a false claim of appearance where teenagers like to 'fake it.' Beauty has always been the contentious subject in most fictional works and specially in fairy tales. Classic fairy tales portray their heroine as a beautiful being, a picture-perfect substance. They are celebrated not for their confidence or bravery, but for their outward appearance, clothing and jewels. Thus, every girl child has a fantasy of finding a Fairy God Mother who can turn her into a stunning, attractive princess and only then, they can meet their prince charming and happily ever after. But things are not the same, they don't have God Mother or they don't want to remain as a beautiful angel, rather, they want to be ordinary with full of courage and confidence to fight back to any evil. They don't need any prince charming to fight for her rather they want to fight for their own. This paper will study the contrast between the classical and modern story of Cinderella in Children Literature and also explore how the concept of beauty is changing in the modern books and fairy tales.
\end{abstract}


Keywords: Beauty, Children Literature, Children books, Cinderella, Fairy tales, Children Psyche.

Literature is considered as one of the main factors influencing people's perception of life. Literature acts as a mirror of the society. It also helps in building one's maturity. Culture, race, ethnicity, gender, class and many other ideologies are directly or obliquely pictured in literature and in fact according to many scholars, these are also been portrayed in children's literature, especially in fantasy tales. Previously children books were written only to give them moral lessons and, in a way, books were used to shape one's personality. Parents belief, they will also adversely lead to the development of the beliefs and attitudes of their children and from them, they can have an perceptions of real life. Literature is important for people's psychological, emotional and social development, and it can have a very strong effect on children during their vulnerable age, when their personalities start to form. Children are very sensitive. They do things on the basis of their own emotions. They're really happy to do the right thing, and they're guilty of doing the wrong. Literature helps to convey their internal feelings. It also helps to alert them about the threats around them and heighten the knowledge; it shapes their belief and develops the responses towards society and assists children to points up with other people's feelings and problems, and shows them how to cope with their own. It is also an escape; escape from the harshness of reality and opens the doorway of imaginary world. The characters of the literature become their role models and they follow their every footstep. They start to equate themselves with those characters. Literature is that teacher of people who imparts social and cultural values to every generation. Childhood is a time of tenderness. It decides what sort of person someone is going to become in the future. Thus, parents, researchers, educators are very mindful of their duties for any child. Children's literature is an instrument for the creation of conscientious and wise 
generations. Considering the limited spectrum of children's preferences, the most suitable writing types for children can be considered short tales and comics.

Narration is the cornerstone of our life. Thus, short stories and tales have a significant role to play in our culture. Fairy tales, one of the forms of short stories has been transferred from Decade to decade for countless generations. It has been transformed, reconstructed and restructured in many cultures and periods of time. The versatility and progression of children's stories have guaranteed their sustainability and made them even more important for exploration and research. Fairy tales allow us to better understand the underlying complexities of human nature, the truths. These stories have been passed down through generations, from storytellers to listeners for decades. Many of these narratives centre on common themes like family, good vs. bad, love, romance, passion, devotion and more. These stories portray those particular aspect of human existence and mainly explain human hopes, expectations, desires and feelings. Fairy tales are short and simple. It mainly developed from the old tradition of storytelling. The short length of those tales keeps the reader's interest and curiosity intact and helps them to finish it at one sitting.

The root of fairy tales and folk tales is a much argued and explored topic. Literary scholars in various occasions and researches highlight the development of fairy tales, from the popularity of the storytelling in the court of Mme d'Aulnoy to the invention of the printing press to the collection and publication of many tales by the Brothers Grimm. From the legends of the oral tradition, literary fairy tales developed, layer by layer, in the various cultural communities where they bridged and transmitted these oral tales. A particular form of folk tale tradition, Fairy tales are mostly known as fantasy stories, although not all of them specifically contain magic. This group of thinkers describes folk tales as being shared and preserved by oral tradition and with the advent of a 19th century and printing press these stories further reinforced. Another school of thinkers believe that literary fairy tales acquired 
the power and prominence as a kind of club activity for upper class French ladies, and those stories were meant for adults rather than children.

Starting with once upon a time and ending with happily ever after, fairy tales hold some unique characteristics which deviate them from any other writings. Here, animals can talk, sing and sometimes help the protagonist to find their right way. Witches, fairies, goblins and other magical creatures also exist. These tales can be heard all around the world from various authors and tellers in multiple variations. The tradition of telling stories is from ancient's times. Previously, it was considered a craft. Later, these fairy tales were primarily used to entertain or frighten children. Today, with the arrival of technologies and the growth of pop culture, many of these masterworks have been developed into animations. By incorporating digital tools, and special effects these stories got their visual representation. Through this, more audiences around the world have directly influenced people, particularly children.

One of the core aspects of fairy tales and animation is the idea of perfection and beauty. It's often said that different people have separate concepts of beauty and it depends on the eyes of the spectator. But apart from this, there has to be a specific explanation about beauty. Beauty is a subject of perception and admiration; that's well defined as it is placed next to ugliness. One may say, by way of dichotomy, that attractiveness and beauty is the opposite of ugliness. A study which is commissioned by Dove, one of Unilever's largest beauty brands, entitled: "The Real Truth About Beauty study" was done 'to explore empirically what beauty means to women today and why that is.' (Etcoff) It was mainly a survey consisted with the data of 3,2000 women in between the age group of 18 to 64 . The survey's result was very unexpected. It provided some fascinating aspects from women's points of view on the concept of beauty. Majority of the total respondents firmly believed that physical beauty applies to how someone looks, while beauty reflects who an individual is. 
For them, beauty lies in people's kindness, confidence, honesty and believe. Beauty is not measured anymore and its meaning varies from individual to individual from every now and then.

But in certain fairy tales, some stereotypic ideas of beauty are encouraged, and the female protagonist represents only her physical beauty. Thus, it is often said that, fairy tales may have a negative impression on children and their attitude towards life can be affected by that. It is only reason that some of the researchers criticised them repeatedly. These tales objectify women as weaker sex, craving for help, always require male encouragement, either as a lover or otherwise: they always need to be beautiful and attractive to impress her partner. As in the article 'Witches and Fairies: Fitzgerald to Updike', Lurie talks about the fact that how women are being misrepresented by these fairy tales and she also points out that some of the scholars find fairy tales very offensive and for them: "“"Cinderella" and "Snow White" is a sort of brain-washing, intended to convince them that all little girls must be gentle, obedient, passive, and domestic while they wait for their prince to come." (Lurie) Lieberman in her writings also claims the same.

The tales of Cinderella are by far the most popular forms of fairy tales currently known; for centuries it has existed. Cinderella legends are presented in several different parts of the globe as well as in different periods of time. Studying the history of the narrative as well as the gaps between interpretations of the stories since they are linked to multiple writers and time space, it becomes easier to bring to light the patterns and topics associated with racial and social relations as well as other relevant issues. This has also been contained in the mythologies of Greeks, Romans, Egyptians, and Chinese. Though, it has not historically been present in Australia, Africa or the Americas, it has subsequently spread to these areas. Cinderella tales are cyclical stories in which heroines are introduced as living with a caring father in a middle to upper class due to their character, birth, and other attributes, but from 
which they are departed or are pushed out of. These heroines need to be truthful, loyal, devotional, hard-working in order to restore her class and environment. These tales usually praise the good, the wise, and the fair, and condemn the bad.

In the story of Cinderella by Jacob and Wilhelm Grimm, the word 'beautiful' is used numerous times and the meaning, it is carrying only screams about the physical beauty of a person. In the very outset of the story while describing the two step sisters, Grimm brothers depicts: "They were beautiful, with fair faces, but evil and dark hearts." (Grimm) which shows beauty can only equate with fairness. Here, beauty, fairness, white is opposed to evil, dark and black. In the King's proclaimed festival only

"All the beautiful young girls in the land were invited, so that his son could select a bride for himself." (Grimm)

This proclamation from the Castle of the King reflects the value of attractiveness in this fairy tale. As a wife, the prince is searching for a stunning, beautiful young lady and there are no other requirements, such as strong morality or courage and dignity. The importance of cosmetics and dresses to look pretty is also encouraged. Thus, Cinderella is rejected to go to the festival by her step mother as she

“...have neither clothes nor shoes, and yet you want to dance!” (Grimm).

This fondness of materialistic life is also been reflected in the following section when Cinderella becomes unrecognisable wearing the golden and silver dress with "slippers embroidered with silk and silver."(Grimm)

It was so predominant that:

"Her stepsisters and her stepmother did not recognize her. They thought she must be a foreign princess, for she looked so beautiful in the golden dress." (Grimm) 
In this story Cinderella doesn't wear the attire of courage, confidence and truth rather for the next day she chooses dress even more gorgeous than the previous one and continues to do such in the third day.

Though the prince danced with Cinderella for the last three days, he doesn't have a single clue about the identity of Cinderella and her personality. Thus, he declares:

"No one shall be my wife except for the one whose foot fits this golden shoe."(Grimm)

Happiness and love come with beauty and beauty comes with a price and compromise. Thus, the step mother doesn't hesitate to advise her daughters to cut off their toes and heels. In the end beauty puts away its last impression in the prince's final discission where only after looking at Cinderella's face

"he recognized the beautiful girl who had danced with him. He cried out, "She is my true bride." (Grimm)

In The Egyptian Cinderella (1989), by Shirley Climo, a different version of Cinderella is waiting to get her happily ever after. This is a story of a slave girl named, Rhodopis who was kidnapped and sold by pirates in Egypt. Here, the torture of the step mother and two step sisters were replaced by three other household servants who are comparatively not that attractive as Rhodopis. These three servants harassed her in several occasions. Impressed by the dancing of Rhodopis, her master designed a pair of red-rose gold slipper. On the occasion of pharaoh's feast, Rhodopis is naturally left behind to do the households. But, in the end rescued by a falcon, she finds her hero and marries to him. In The Egyptian Cinderella, the representation of beauty can easily be seen in the drawings of this tale from the very first look. The illustrator revealed those three servant girls as shadowy brown skin and straight hair, while Rhodopis, the Greek slave, was seen with vivid red skin, green eyes and golden hair. In fact, the comparison was so vivid as they were put together in the same page. These 
concepts and features of beauty not only draw a false description of beauty but also convey the false message of how a girl needs to look and act to win a noble man. Similarly, the notion that the man is the rescuer, the one who has the power and wealth and always chooses beautiful girl as his life partner is a misleading on beauty and gender and educators should exclude those representations from literature for children.

Nowadays, technology allowed beauty to be visualised. In animation, cartoons, films of Walt Disney, the concept of beauty is pictured with lavish palaces, luxuries, handsome prince, ruthless step families. Heroines possess the features of barbie doll: way too beautiful girl with angelic qualities, round big eyes, long eye lashes, small nose, pink lips, slender figure, long hair, fair and light complexion. In the comic books of Disney, the female protagonist Cinderella is a pretty, fair-skinned blond girl who is friends with animals. She is frail, naive, and shows no signs of confidence or strength. She should have protected her rights and prevented her step family from bullying her, but what she did was sob and wait for someone to support her.

In an e-article "What I Want My Daughter to Know About Beauty" by Jolene Vossen for Wichita Mom, a mother expresses her feelings while watching her eight years old daughter putting her makeup and "way too bright pink lip stick" that:

"This world will tell her she should be prettier, I want her to know "pretty" truly exists deep in one's heart. This world will tell her she has to be skinnier, I want her to love the body she has been given, eat healthy and treat it well." (Vossen)

Firstly, it points out how beauty continues as the key part of the society and how young children are being affected by this beauty standers. Physical appearances, 'looking perfect' are always been projected as the primary factors in many fairy tales and Cinderella is a perfect example of it. The only reason behind the envy of the step mother and two step sisters of Cinderella is her outer beauty and in fact later it becomes the sole reason of the 
prince charming to choose Cinderella over any other girls. Though it is hidden but somehow beauty plays as a prime card and influences the tales to create plots, problems and the happily ever after.

All these qualities of Cinderella might sometimes put the reader to question that, why is she the heroine of the story?! Children become so fascinated with the images and shiny representation and inspired by all these artificialities that they often try to imitate some of these features into themselves. But is Cinderella the right one to choose? Cinderella specifically guides kids to physical and materialistic perfection. Cinderella only succeeded because she was pretty and she carried gold and silver costumes. That is far from the practical world; kids nowadays need to realise that it doesn't matter whether they attribute any beauty or not, they are wealthy or poor, there are several other ways to accomplish their goals.

In order to accomplish different purposes ranging from social critique to teaching, Cinderella tales employ the device of shifts in body image, physical appearance and role within the family. These stories point to various values, ranging from the importance of self, wellness, liberty and brilliance to indifference. In 1997 a new Cinderella was discovered in Rodgers \& Hammerstein's Cinderella. This American musical fantasy television film was produced by Walt Disney Television and directed by Robert Iscove and written by Robert L. Freedman. Adapted from the story by Oscar Hammerstein II, Freedman modernised the script by updating its concepts, particularly rewriting its lead character into a stronger heroine, to appeal to more contemporary viewers. The creators opted to employ a colour-blind casting process to represent how society had changed in the 1990s, with Brandy being the first black actress to play Cinderella on the screen. Despite being diverted from the originalities of Cinderella story, this film proved a huge hit in ratings, initially broadcasting to 60 million viewers and marking itself as the most viewed musical television in history, gaining $\mathrm{ABC}$ the best ratings in 10 years on Sunday night. The Cinderella of Rodgers \& Hammerstein was 
nominated for many television nominations, including seven Primetime Emmy Awards, earning one for exceptional Character Design. Disney and $A B C$ were encouraged to produce other related musical collaborations by the popularity of the show. Due to the extraordinary representation of its cast and Brandy's performance, Rodgers \& Hammerstein's Cinderella is viewed by contemporary critics as a landmark film.

The adaptation of the story of Cinderella by Donaldson as The Cinderella Play (Oxford Reading Tree Songbirds Phonics Level 5) is quite unique. Though a play acted by children, here Cinderella is pictured as ordinary girl. She wears glasses. The girl on wheelchair acts the part of fairy god mother. Though a book of learning phonics for younger children, this illustration breaks several stereotypical myths and its representation of the story of Cinderella. Putting the drawings of the protagonist as not a beautiful gorgeous being, rather, an ordinary simple girl, the creator slips the idea into the young mind that any girl has the ability to attain their success.

In a e-article on The Wire, it has been reported that in the sociology textbook recommended for class XII students by the Maharashtra State Board of Secondary and Higher Education, impairment has been claimed as a factor of dowry. It further illustrates the helplessness of the family of disabled girl during the time of marriage. Literature is one of the most important instruments in influencing human actions, mindset and perceptions and its powerful impacts can be both helpful and damaging. Children, the vulnerable group of people, takes message and inspiration from short stories, fairy tales and animations. The representation of Physical beauty in the classical fairy tales thus explains lots about the children's inclination towards designer clothing, makeup, cosmetic surgery. If children are introduced to reading proper books with proper portrayal of class, beauty, gender and other beliefs, it is possible to envision a world where beauty is no longer a matter of concern. Every girl is a Cinderella of her own and her happiness depends on herself. And now it's essential 
for everyone to protect themselves from false convictions and liberate oneself from the restraints of tradition. 


\section{Works Cited}

Etcoff, Dr. Nancy, Dr. Susie Orbach, Dr. Jennifer Scott, Heidi D’Agostino. THE REAL TRUTH ABOUT BEAUTY: A GLOBAL REPORT. 2004.

Grimm, Jacob and Wilhelm. Cinderella. https://www.pitt.edu/ dash/grimm021.html. Accessed 20 Dec. 2020.

Lurie, Alison. Witches and Fairies: Fitzgerald to Updike, 2 Dec. 1971, www.nybooks.com, https://www.nybooks.com/articles/1971/12/02/witches-and-fairies-fitzgerald-toupdike/. Accessed 15 Dec. 2020.

Vossen, Jolene. "What I Want My Daughter to Know About Beauty". Wichita Mom, 12 May.2015,https://wichitamom.com/parenting/what-i-want-my-daughter-to-knowabout-beauty/. Accessed 1 Jan. 2021. 